NEWS

\title{
Climate talks snarled up
}

Two-pronged negotiations fail to bridge divide between nations.

International climate negotiators muddled through the latest round of global-warming talks in Bonn, Germany, last week, overshadowed by independent bilateral negotiations in Beijing between the United States and China.

Neither meeting produced any significant breakthroughs, and new disagreements seem to have outnumbered resolutions by a wide margin. At the United Nations climate talks that ended on 12 June in Bonn, delegates proposed so many new provisions and wording changes that the negotiation text ballooned fourfold to more than 200 pages - standard procedure for such negotiations, but one that flags up how much work remains to be done.

"We're at the point where we desperately need some higher-level leadership to get this process going," says Keya Chatterjee, deputy director for climate change at the WWF environmental group in Washington DC.

Many observers placed their hopes instead on the talks in China, which played host during 7-10 June to a US delegation led by Todd Stern, the nation's lead climate negotiator, and John Holdren, President Barack Obama's chief science adviser.

The two countries together produce some $40 \%$ of global greenhouse-gas emissions, and there is little chance of achieving an international agreement in Copenhagen, where the UN talks are scheduled to conclude in December, unless the United States and China come to

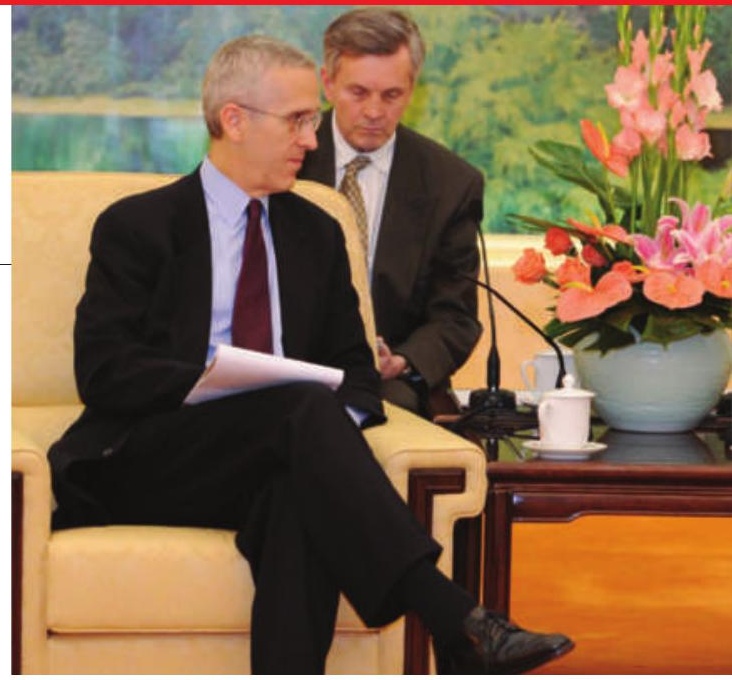

an understanding. Nonetheless, expectations going into the Beijing meeting were low.

China released a position statement on 20 May calling on developed nations to reduce emissions to at least 40\% below 1990 levels by 2020. The leading US climate legislation - a bill that could come up for a vote as early as this month in the House of Representatives - would establish an emissions-trading system to reduce US emissions to 1\% below 1990 levels by 2020 . Other provisions in the bill would go further,

\section{Patchy pig monitoring may hide flu threat}

Public-health experts are warning that a lack of surveillance may be allowing the 2009 pandemic H1N1 flu virus to go undetected in pigs. This raises the risk that the virus could circulate freely between humans and pigs, making it more likely to reassort into a deadlier strain, they say.

Pig surveillance is largely the remit of animal-health organizations, agriculture ministries and the farming industry. Their main concern tends to be that any reports of the pandemic virus in pigs might provoke overreactions such as the mass culling of pigs that took place in Egypt, or trade bans on pigs and pork. Within minutes of the World Health Organization (WHO) announcement on 11 June that swine flu had become a pandemic, Bernard Vallat, directorgeneral of an intergovernmental trade body, the World Organisation for Animal Health (OIE), had reiterated that trade sanctions were unjustified. "So far the role of animals has not been demonstrated in the virus's epidemiology or spread," he asserted.

But some experts say that is an artefact of patchy to

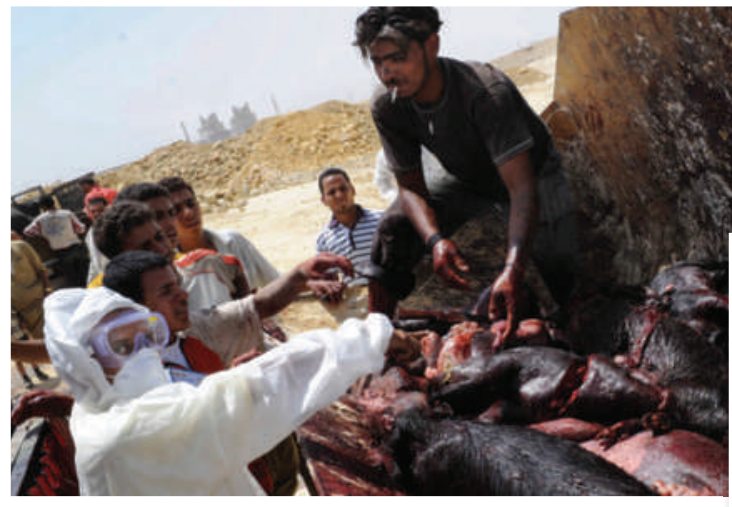

Egypt has seen mass culling of pigs (above). WHO director-general Margaret Chan (right) last week declared that the new swine flu virus had reached pandemic status.

non-existent flu surveillance in pigs. In a paper published last week (G. J. D. Smith et al. Nature advance online publication doi: 10.1038/nature08182; 2009), Gavin Smith, a flu geneticist at the University of Hong Kong, and his colleagues concluded that "the lack of systematic swine surveillance allowed for the undetected persistence and evolution of this potentially pandemic strain for many years". The virus originated from a mixture of swine flu strains, and pigs are an "obvious" part of the epidemiology of the new virus, says Smith. Yet the number of swineflu sequences in the international GenBank database is about a tenth of that for avian flu viruses. Circulation of the virus between pigs and humans is "definitely a possibility", he adds.

The pandemic virus has so far been found in pigs from just one farm, in Alberta, Canada, where it spread throughout the herd. But noone has been able to pin down how the herd became infected. Scientists at the Veterinary
Laboratories Agency in Weybridge, UK, have shown that pigs can easily become infected with the virus, and readily transmit it between themselves and shed it into the environment. Past pandemic viruses have also gone on to become endemic in pig populations.

"It's absolutely surprising that a virus this contagious in both humans and swine, and which has been reported in humans in 76 countries, has only been reported in one swine farm in Canada," says Jimmy Smith, head of livestock affairs at the World Bank in Washington DC, and a member of the organization's flu task force. "It is highly likely that more pigs are infected in more places."

Absence of evidence of the pandemic virus in pig populations is not evidence of absence, concedes Steve Edwards, chairman of the OIE-FAO Network of Expertise on Animal Influenza (OFFLU), which coordinates work done by animalflu surveillance labs worldwide, and former chief executive of the 
